Animal Health Research Institute,

Assiut Regional Laboratory.

\title{
PREVELANCE OF CLOSTRIDIUM PERFRINGENS AND ITS ENTEROTOXINS IN RAW MEAT AND POULTRY IN ASSIUT CITY
}

(With 2 Tables and One Figure)

By

GHADA M. MOHAMED and LUBNA M. EBRAHEEM (Received at 16/5/201)

مدى تواجد ميكروب الكلوستريديم بيرفرنجنز وسمومه فى اللحوم الطازجة

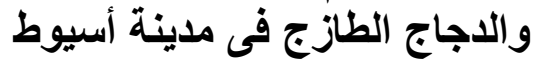

غادة محمد محمد ، لبنح محمد إبراهيم

تم جمع 120 عينة من اللحوم و الدجاج بو اقع 60عينة من اللحوم من محلات الجزارة المختلفة مدية

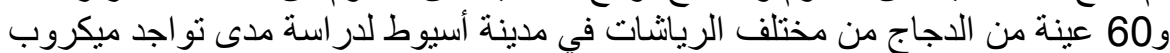

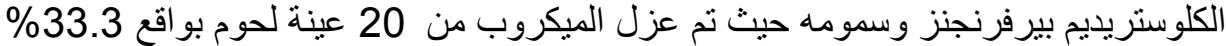

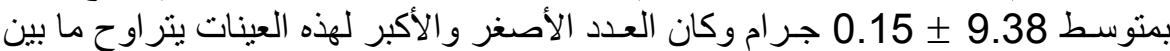

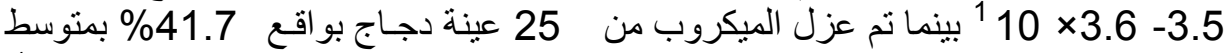

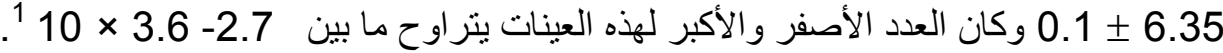
وقد تم تحديد الجين المسئول عن سموم الكلوستريديم بيرفرنجنز بواسطة الإنة اختبار انزيم البلمرة

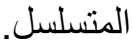

\section{SUMMARY}

A total of 120 samples of raw buffalo meat and poultry carcases were collected from different butchers shops and poulteres processing shops in Assiut City to study the prevalence of Clostridium perfringens and their toxins. Cl.perfringens was isolated from 20 (33.3\%) of the meat samples with a mean value of $9.38 \pm 0.15 \mathrm{MPN} / \mathrm{g}$, the minimal and maximal numbers in these samples varied from $3.6-3.5 \times 10^{1}$. While 25 (41.7) of poultry samples were positive for Cl.perfringens where the mean value was $6.35 \pm 0.1 \mathrm{MPN} / \mathrm{g}$, with a minimum of 3.6 and a maximum of $2.7 \times 10^{1}$. The presence of the Cl.perfringens enterotoxin (CPE) was determined by PCR using previously published primer sequences. 
Key words: Meat, poultry, C.perfringens, PCR.

\section{INTRODUCTION}

Clostridium perfringens is a leading cause of bacterial foodborne illness in countries where consumption of meat and poultry is high (Lin and Labbe, 2003).

Cl.perfringens is an anaerobic sporefoming and ubiquitous pathogen bacterium widely distributed in the environment and frequently occurs in soil, water and the intestinal tract of certain animals and humans (Omer et al., 2005).

Illness occurs due to consumption of large numbers $\left(>10^{6}\right)$ of viable vegetative cells of $C$ l.perfringens per gram of implicated food, followed by sporulation and enterotoxin (CPE) formation in the small intestine (Saito, 1990).

This toxin is both necessary and sufficient for the enteric virulence of Cl.perfringens type A food poisoning isolates. The enterotoxin is a 320 amino acids protein proteolytically activated causing diarrhea and abdominal cramps, sometimes with vomiting and fever (Stringer et al., 1982).

Numerous epidemiological investigations have revealed that the majority of food borne outbreaks are associated with the consumption of meat and poultry products (Brynestad and Granum, 2002).

A recent study suggests that the strong association between type A isolates carrying a chromosomal CPE gene and Cl.perfringens type A food poisoning is attributable (at least in part) to the exceptional heat resistance of those isolates, which should favor their survival in incompletely cooked or improperly held foods (Nasr et al., 2007)

Death from Cl.perfringens type A food poisoning is not common but do occur in the elderly and debilitated. Only a small fraction $(\sim 1$ to $5 \%$ ) of all $\mathrm{Cl}$.perfringens isolates, mainly belonging to type A, carry the CPE gene (Daube et al., 1996).

The purpose of the present study was to determine the occurrence of Cl.perfringens in meat and poultry sold in Assiut markets and to determine the enterotoxin of some strains using PCR technique. 


\section{MATERIALS and METHODS}

\section{1- Collection of samples:}

A total of 120 samples of raw buffalo meat and poultry carcases (60 of each) were collected from different butcher and poulteres shops in Assiut city to be examined for the presence of Clostridium perfringens and their toxins. The samples were transferred separately and aseptically in an ice box without delay to the laboratory of Animal Health Research Institute in Assiut where they were examined.

\section{2- Bacteriological analysis:}

\section{A- Isolation:}

One gram of each sample was aseptically transferred to sterile Cooked Meat Broth (CMB) tubes. Inoculated tubes were anaerobically incubated at $37^{\circ} \mathrm{C}$ for $24 \mathrm{~h}$. From positive tubes which showed turbidity and gas production a loopfull was streaked onto Sulphite Polymyxin Sulfadiazine Agar (S.P.S. agar) plates. Inoculcated plates were incubated anaerobically at $37^{\circ} \mathrm{C}$ for $24 \mathrm{~h}$. Suspected Cl.perfringens colonies, black surrounded by an opaque zone, were picked up and purified for further identification according to the methods outlined by Angelotli et al. (1962).

\section{B- Enumeration (MPN/g): (A.P.H.A. 1992).}

Ten gram portions of each sample were diluted in $90 \mathrm{ml}$ of sterile $0.1 \%$ buffered peptone water and homogenized using a blender at high speed (8000 r.p.m) for 5 minutes to obtain a dilution of $10^{-1}$, then decimal dilutions were prepared using buffer peptone water. One $\mathrm{ml}$. of the previously prepared $10^{-1}, 10^{-2}$ and $10^{-3}$ of the samples was inoculated separately into 3 replicate tubes of Lactose Sulphite (L.S) broth supplied with inverted durham's tubes, and incubated anaerobically at $46^{\circ} \mathrm{C}$ for 24-48h. Lactose Sulphite tubes showing blacking with gas production were recorded and considered positive for Cl.perfringens. Numbers of Cl.perfrings/g were calculated from MPN Table for 3 by using MPN (Most Probable Number) tubes as recommended by AOAC (1990).

\section{C- Identification:}

Clonies thought to be Cl.perfringens were picked up for further confirmation according to Krleg and Holt (1984); Holt et al. (1994).

\section{D- DNA extraction:}

Template DNA was obtained from cultures of the confirmed isolates from chicken and meat ( 3 for each). Cells were grown for $24 \mathrm{~h}$. at $37^{\circ} \mathrm{C}$ in cooked meat media. 
One milliliter of culture was centrifuged at $5.000 \mathrm{xg}$ for $15 \mathrm{~min}$, and the cell pellet was washed twice with sterile saline and resuspended in 200ML of high-pressure liquid chromatography - grade water and then placed in a boiling water bath for $20 \mathrm{~min}$. After centrifugation, $10 \mu \mathrm{L}$ of supernatant fluid was used as the template for PCR. (Tong and Labbe, 2003)

\section{Oligonucleotides:}

Previously described enterotoxin gene (CPE) oligonucleotide primers for the Cl.perfringens that allow the amplification of a $233 \mathrm{bp}$ DNA fragment were used in this work (Meen and Songer, 1997). The forward primer sequence was:

5'-GGA GAT GGT TGG ATA TTA GG and the reverse primer sequence was:

5'- GGA CCA GCA GTT GTA GAT A

\section{PCR reaction conditions:}

For amplification, reaction mixtures (total volume 50 $\mathrm{\mu l}$ ) included $5 \mu 1$ of Taq DNA polymerase assay buffer (SIGMA), 10 $\mu 1$ of template DNA, $1 \mathrm{mM}$ concentrations of each primer, $0.2 \mathrm{mM}$ concentrations of daoxynucleoside triphosphates, $1.5 \mathrm{mM} \mathrm{MgCl}_{2}$, and $2 \mathrm{U}$ of Taq DNA polymerase (Fermentas).

Amplification was carried out in a Bio-RAD thermal cycles with 30 cycles of $1 \mathrm{~min}$ at $94^{\circ} \mathrm{C}, 2 \mathrm{~min}$. at $55^{\circ} \mathrm{C}, 3 \mathrm{~min}$. at $72^{\circ} \mathrm{C}$, and a final extention time of $4 \mathrm{~min}$. at $72^{\circ} \mathrm{C}$. The results were determined by electrophoresis of 20ML of PCR products in a $1.5 \%$ agarose gel for $30 \mathrm{~min}$. at $80 \mathrm{~V}$ and staining with ethidium bromide. The 233-bp PCR products of CPE was observed. PCR marker, 100bp ladder (Promega) was used as standard. Amplified bands were visualized by UV illumination and photographed (Tong and Labbe, 2003).

\section{RESULTS}

Table 1: Incidence of Clostridium perfringens in meat and poultry samples ( $\mathrm{n}=60$ of each).

\begin{tabular}{|c|c|c|}
\hline \multirow{2}{*}{ Tested samples } & \multicolumn{2}{|c|}{ Positive samples } \\
\cline { 2 - 3 } & No. & $\%$ \\
\hline Meat & 20 & 33.3 \\
\hline Poultry & 25 & 41.7 \\
\hline
\end{tabular}


Table 2: Statistical analytical results of Cl.perfringens count/g of meat and poultry samples using MPN Technique ( $\mathrm{n}=60$ of each).

\begin{tabular}{|c|c|c|c|c|c|c|}
\hline \multirow{2}{*}{ Tested samples } & \multicolumn{2}{|c|}{ Positive samples } & \multicolumn{4}{c|}{ Count /g } \\
\cline { 2 - 7 } & No. & $\%$ & Min. & Max. & Mean & \pm S.E \\
\hline Meat 60 & 28 & 46.7 & 3.6 & $3.5 \times 10^{1}$ & 9.38 & 0.15 \\
\hline Poultry 60 & 32 & 53.3 & 3.6 & $2.7 \times 10^{1}$ & 6.35 & 0.1 \\
\hline
\end{tabular}

\section{CPe gene detection (FV1)}

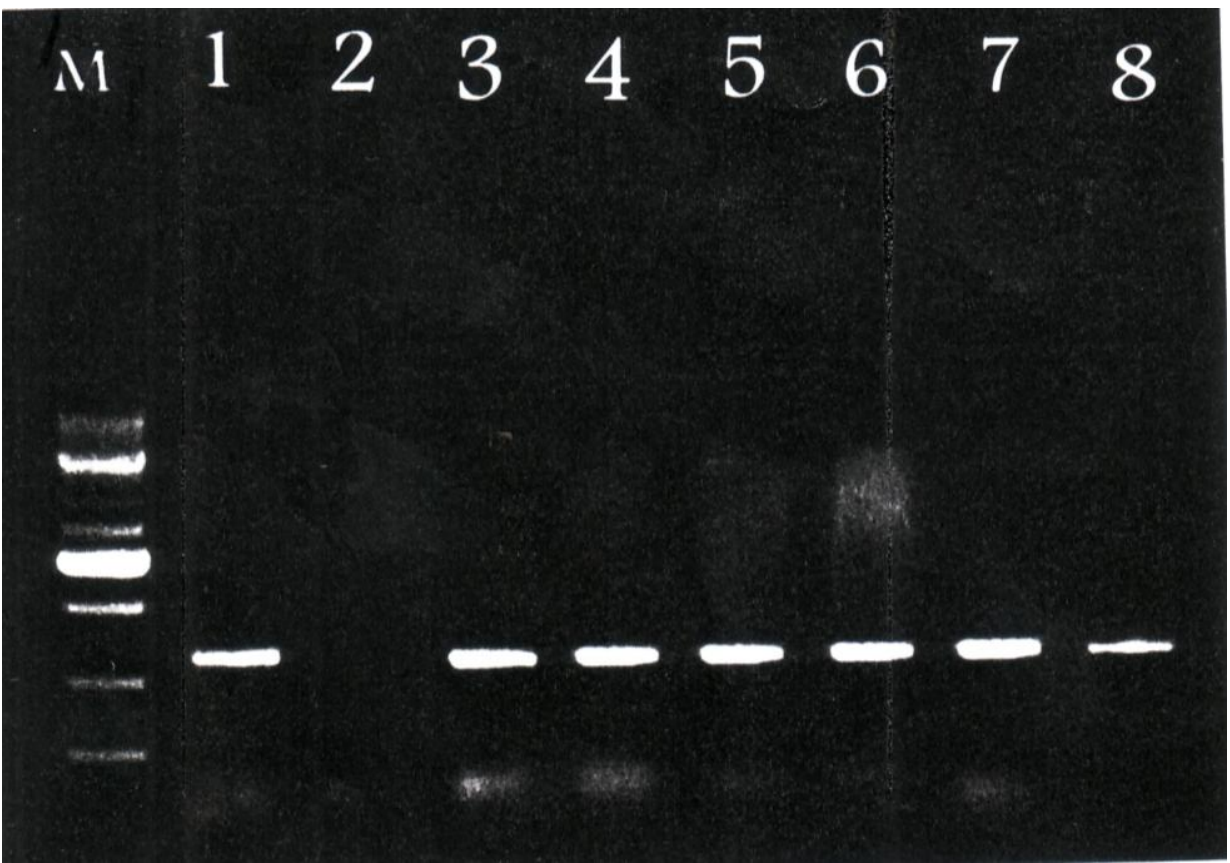

Fig. 1: Agarose gel electrophoresis of amplication products obtained from genomic DNA of Cl.perfringens enterotoxin gene (233bp PCR product).

Lane M: Molecular weight standard (100bp ladder).

Lane 1 : Positive control.

Lane 2 : Negative control.

Lane 3 to 8: Representative Cl.perfringens isolates from meat and poultry samples.

All six reference strains were positive for Cl.perfringens enterotoxin gene in the PCR test with primer pairs. 


\section{DISCUSSION}

Our study purposely surveyed both raw meat and chicken which are commonly implicated as vehicles for Cl.perfringens type A food poisoning outbreaks.

In recent decades many surveys have been conducted on the incidence of Cl.perfringens in raw and processed meat and poultry, these reports indicated widespread occurrence of the organism in meat and poultry (Labbe, 2000).

According to numerous surveys, about $50 \%$ (range 30 to $80 \%$ ) of raw or frozen meat and poultry contains Cl.perfringens (Labbe, 1988).

As shown in Table 1, 33.3\% of the meat samples tested in the present study were found to be contaminated with Cl.perfringens and these results are nearly in agreement with those published by El-Mahrouk (2007) who reported an incidence of the organism in meat samples as 39\%. The results also in agreement with Wen and McClane (2004) who detected the contamination rates of the organism ranging between $20-40 \%$ from all the examined meat samples. Rodriguez et al. (2002) revealed that Cl.perfringens were isolated from $42(55 \%)$ out of 76 samples of slaughtered meat and 30 $(61 \%)$ out of 49 retail meat which were higher than that recorded in this study. On the other hand, Miwa et al. (1984) reported the isolation of Cl.perfringens from $2 \%$ of the examined meats by using PCR technique which seemed to be lower than our results.

The same Table revealed that $41.7 \%$ of poultry samples tested in the present study were found to be contaminated with Cl.perfringens and these results agreed with El-Khateib et al. (1988) who found the organism in percentage of $40 \%$ of raw chicken meat products. However Nasr et al. (2007) could isolate the organism from $46.6 \%$ of chicken fillet.

The prevalence of Cl.perfringens in poultry samples tested in the present study was higher than that reported by Lin and Labbe (2003) where they found this bacterium in $39(29.5 \%)$ of the 132 samples including chicken meat, chicken leg and chicken neck. Similarly Saito (1990) and Miwa (1984) isolated the organism from 24\% and 12\% of chicken meat samples. 
In contrast to this and previous other studies high incidence was reported by other researchers: Omer et al. (2005) found this bacterium in $28(70 \%)$ of 40 ground poultry samples. Miwa et al. (1998) detected Cl.perfringens in 42 (84\%) of 50 chicken samples examined and Nasr et al., (2007) reported the incidence of this organism in chicken quarter as $57.9 \%$. On the other hand, Ternstrom and Molin (1987) Fail to detect the organism in chicken samples.

By using the MPN technique, the results outlined in Table 2 indicated that the incidence of Cl.perfringens in meat samples was $46.5 \%$ and had MPN/g values ranging from 3.6-3.5 $\times 10^{1}$ with a mean of $9.38 \pm 0.15 \mathrm{MPN} / \mathrm{g}$. This observation is in agreement with El-Mahrouk (2007) who reported a range of 0-35 MPN/g. Moreover, Lin and Labbe (2003) and Wen and McClane (2004) tested the MPN/gram in retail foods and found that its values ranged from 0-32. Similary Miwa et al. (1984) recorded $<10^{2} \mathrm{MPN} / 100 \mathrm{~g}$ of the organism in meat samples. While Rodriguez (2002) recorded an average of $2.2 \times 10^{4} \mathrm{MPN} / \mathrm{g}$ of the organism in slaughtered meat and $8 \times 10 \mathrm{MPN} / \mathrm{g}$ of retail meat which are considered higher than that recorded in our study. At the same Table the incidence of Cl.Perfringens in poultry samples was $53.3 \%$ and had $\mathrm{MPN} / \mathrm{g}$ values ranging from 3.6-2.7 $\times 10^{1}$ with a mean of $6.35 \pm 0.1$ MPN/g. These results are considered lower than that obtained by Miwa et al. (1984) who recorded $<10^{2}-4.3 \times 10^{2} \mathrm{MPN} / 100 \mathrm{~g}$ of chicken samples. Also our results considered highest than that obtained by Omer et al. (2005) who recorded a mean number 2-6 MPN/g of ground poultry samples with minimal and maximal numbers varied from 0.3-9.3 MPN/g. Miwa et al. (1998) detected Cl.perfringens in chicken samples at the level of $<10^{2}$ and $10^{4} \mathrm{MPN} / 100 \mathrm{~g}$. which seem to be higher than that recorded in the present investigation.

Clostridium perfringens isolates are commonly classified into five types (A to E) based on the production of four typing toxins (alpha, beta, epsilon and iota toxins) (Songer, 1996). Type A isolates, the most abundant toxinotype, produce alpha toxin, but not beta, epsilon, or iota toxin (Immerseel et al., 2004). Some type A isolates also produce another toxin, Cl.perfringens enterotoxin (CPE). These enterotoxigenic type A strain cause several human enteric diseases, including Cl.perfringens type A food poisoning, which is among the three most common food borne illnesses in the United States, and some cases of 
non-food-borne human gastrointestinal disease, including antibiotic associated diarrhea and sporadic diarrhea (Carman, 1997).

Concerning the detection of cpe gene of Clostridium perfringens, several investigators have reported it (Shalaby and Elmabrouk 2006; Naser et al., 2007).

Interpretation of results given in Fig. 1 revealed that 6(13.3\%) out of 45 positive isolates confirmed as Clostridium perfringens strains choosen for PCR identification were positive for cpe gene.

Shalaby and Elmahrouk (2006) used PCR assays to detect cpe production gene as a method for determining the enterotoxigenicity of Cl.perfringens isolates. They stated that PCR is suitable for detection of Cl.perfringens enterotoxin gene from raw meat. Our results were in agreement with Nasr et al. (2007) who used PCR for confirmation of the presence of enterotoxin (CPE) in the predicted $233 \mathrm{bp}$ fragment.

In conclusion, most meat and poultry meat exposed for sale in Assiut markets proved to contain Cl.perfringens. Determining the toxin genotypes of $C l$.perfringens gens is epidemiologically significant, since Cl.perfringens type A food poisoning is nearly caused by cpe positive type A isolates. PCR assay is suitable for detection of Cl.perfringens enterotoxin gene. More studies are needed to overcome the presence of enterotoxigenic $C l$.perfringens in meat and poultry.

\section{ACKNOWLEDGMENT}

We thanks Prof. Dr. Mohmaed Galal Aggour, Director of Animal Health Research Institute, Dokki, Giza for his excellent technical assistance in sequencing data analysis.

\section{REFERENCE}

AOAC "Association of Official Analytical Chemists" (1990): Official Methods of Analysis of the Association of Official Analytical Chemists. $15^{\text {th }}$ ed. Inc. USA. AOAC.

A.P.H.A. "American Public Health Association" (1992): Standard Methods for the Examination of Dairy Products. $16^{\text {th }}$ Ed., American Public Health Association, Washington, D.C. 
Angelotli, R.; Hall, H.E.; Foster, M.J. and Lewis, K.H. (1967): quantitation of Clostridium perfringens in foods Appl. Microbiol. 10: 193-199.

Brynestad, S. and Granum, P.E. (2002): Clostridium perfringens and food born infection. J. Food Microbiol. 74: 195-202.

Carman, R.J. (1997): Clostridium perfringens in spontaneous and antibiotic - associated diarrhea of man and other animals. Rev. Med. Microbiol. 8: 43-45.

Daube, G.; Simon, P.; Limbourg, B.; Manteca, C.; Mainil, J. and Raeeken beek, A. (1996): Hybridization of Clostridium perfringens isolation with gene probe for toxins and for sialidase. Am. J. Vet. Res. 57: 496-501.

El-Khateib, T.; Abd El-Rahman, H.; Hamdy, M. and Lotfi, A. (1988): Poultry meat product in Egypt. Proximal chemical composition and microbial quality. Flechwirschaft. 68 (6): 756-757.

El-Mahrouk, A.M.O. (2007): Electrophoretic characterization for detection of Clostridium perfringens enterotoxin type (A) in meat. Assiut Vet. Med. J. 53, 115: 1-11.

Eman, M. Nasn; Amal, A. Shehta and Hala, A. Amer (2007): Enterotoxigenicity and typing of Clostridium perfringenes isolates from some poultry products in Egypt. J. Appl. Sc. Res. 3 (12): 1804-1808.

Holt, J.G.; Kriege, N.R.; Sneath, P.H.; Staley, J.T. and Williams, S.T. (1994): Bergey's Manual of Determinative Bacteriology, $9^{\text {Th }}$ Ed., Williams and Wilkins, Baltimore.

Immerseel, F.V.; Buck, J.D.; Pasmans, F.; Huyghebaert, G.; Pasmans, F. and Ducatelle, R. (2004): Clostridium perfringens in poultry: an emerging threat for animal and public health. Avian Pathol. 33: 537-549.

Krieg, N.R. and Holt, G. (1984): Bergey's Manual of Systematic Bacteriology Williams and Wilkins, Baltimore.

Labbe, R.G. (1988): Clostridium perfringens in Doyle, M.P. Foodborne bacterial pathogens. New York P. 191-234.

Labbe, R.G. (2000): Clostdidium perfringens in: Lund, B.M., BairdParker, T.C., Gould, C.W. Eds. The microbiological safety and quality of food. Vol. 11: 1110-1135.

Lin, Y.T. and Labbe, R. (2003): Enterotoxigenicity and genetic relatedness of Clostridium perfringens isolates from retail food in the United States. Appl. Environ. Microbiol. 69: 1642-1646. 
Meer, R. and Songer, J.G. (1997): Multiplex polymerase chain reaction assay for genotyping Clostridium perfringens. Am. J. Vet. Res., 58: 702-705.

Miwa, N.; Nishina, T.; Kubo, S.; Atsumi, M. and Honda, H. (1998): Amount of enterotoxigenic Clostridium perfringens in meat detected by nested PCR. J. Food Microbial. 42: 195-200.

Omer, C.; Seda Bilir, O.; Mihittin, T. and Irgan, E. (2006): Presence and contamination level of Clostridium perfringens in raw frozen ground poultry and poultry burgers. Turk. J. Vet. Anim. Sci. 30: 101-105.

Rodriguez, E.; DelMar, G.M. and Vargas, P. (2002): Clostridium perfringens in raw and cooked meats and its relation with the environment in Costa Rica. J. Archivos Latino Americanos. 52: 155-159.

Saito, M. (1990): Production of enterotoxin by Clostridium perfringens derived from humans, animals, food and the natural environment in Japan. J. Food Prot., 61: 240-243.

Shalaby, B. and Elmahrouk, A.M. (2006): Detection of enterotoxigenic Clostridium perfringens type A in camel meat. Vet. Med. J. Giza 54 (1): 179-188.

Songer, J.G. (1996): Clostridial enteric disease of domestic animals. Clin. Microbiol. Rev. 9: 216-234.

Stringer, M.F.; Watson, G.N. and Gilbert, R.J. (1982): Clostridium perfringens type A: serological typing and methods for the detection of enterotoxin. Applied Bacteriology, PP: 111-135.

Ternstrom, A. and Molin, G. (1987): Incidence of potential pathogens on raw beef and chicken in Sweden with special reference to Erysiplothrix-rhusiopathiae. J. Food Prot. 50 (2): 141-146.

Tong, $Y$. and Habbe, R. (2003): Enterotoxigenicity and genetic relatedness of Clostridium perfringes isolates from retail foods in the United States. Applied and Environmental Microbiology, P., 69, 3: 1962-1964

Wen, Q. and MicClane, B.A. (2004): Detection of Clostridium perfringens type A isolates in American retail foods. Appl. Environ. Microbiol. 70: 2685-2691. 